\title{
INTERVIEW WITH HAIGANUCH SARIAN: REFLECTIONS ON THE GREEK WORLD AND THE ANCIENT NEAR EAST
}

\author{
Keywords
}

Classical Archaeology; Museum of Archaeology and Ethnology University of São Paulo; French School at Athens; Greek World; Ancient Near East.

\section{Palavras-chave}

Arqueologia Clássica; Museu de Arqueologia e Etnologia - Universidade de São Paulo; Escola Francesa de Atenas; Mundo grego; Antigo Oriente Próximo.

The following text is a slightly modified transcript of an interview given by Prof. Haiganuch Sarian at the Museum of Archaeology and Ethnology of the University of São Paulo (MAE-USP) to Heródoto on November 22 and December 14, 2016. On both occasions, Prof. Sarian was interviewed by Prof. Gilberto da Silva Francisco.

Professor Sarian is one of the leading researchers on Archaeology of Ancient Mediterranean in Brazil and a well-known international scholar. In Brazil, she has been an active figure in several fields of undergraduate, graduate and extension training. She has also invited several experts, such as Paul Courbin, François Lissarrague, Roland Étienne, Annie Bélis, Dominique Mulliez, Marie Françoise Billot, and Phillipe Bruneau, among others, to teach courses and/or give lectures at the University of São Paulo.

First at the Department of Anthropology in the FFLCH-USP, then at the Museum of Archaeology and Ethnology (MAE-USP), Dr. Sarian has guided postgraduate researches covering the fields of Greek and Roman archaeology, Etruscan studies and Egyptology. Many of her former graduate students are now active professionals at Brazilian public universities such as USP, Unicamp, UFPel, UFRJ, UFBA and Unifesp. Internationally, she has authored several entries in reference works such as the LIMC (Lexicon Iconographicum Mythologiae Classicae) and ThesCRA (Thesaurus Cultus et Rituum Antiquorum), and she is the person 
responsible for the archaeological researches linked to the Sanctuary of Hera in Delos, under the auspices of the French School of Athens (École Française d'Athènes, EFA), where she is currently a senior member.

The themes of this interview with Prof. Sarian are related to some aspects of her researches - which encompass a quite broader array of themes more closely linked to the focus of Herodotus: namely the Classical world and its African-Asian connections. These specific themes were brought up by Prof. Gilberto da Silva Francisco, one of the current editors of the journal, and were previously sent to Prof. Sarian. The interview was transcribed by the following students, who kindly accepted to cooperate with this issue: Diego Henrique Pires (PUC-Campinas), Erik de Lima Correia, Jemima Novaes Siqueira, and Kelly Freire Delmondes (Unifesp). We are deeply thankful for their collaboration.

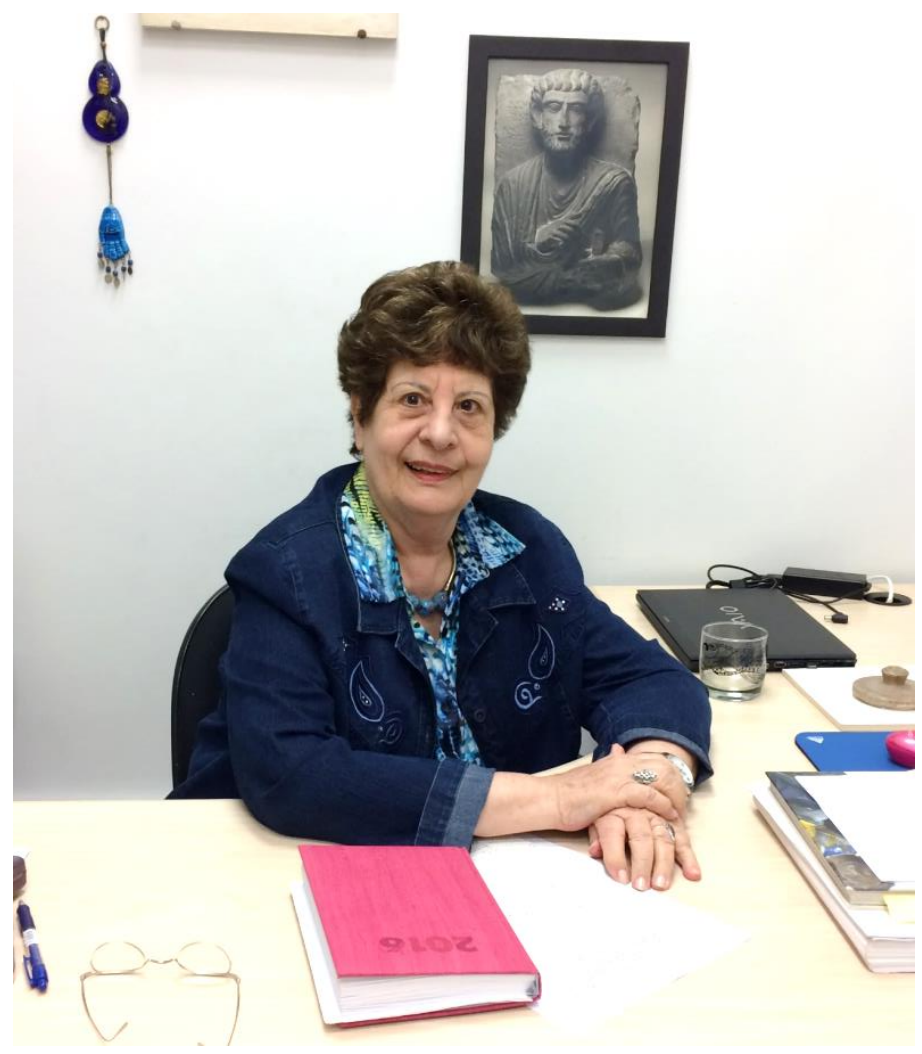

Figure 1: Professor Haiganuch Sarian in her room at the Museum of Archaeology and Ethnology of the University of São Paulo (MAE-USP). To the right above her is a photo of a funerary relief from Palmyra. 
HAIGANUCH SARIAN (H.S.): Thank you for your invitation to interview me. Before answering your specific questions, please let me briefly introduce myself. I am Professor Haiganuch Sarian, now retired as Senior Professor at the Museum of Archaeology and Ethnology and a scholar of its Graduate Program in Archaeology.

Many of your questions are related to the MAE and its Mediterranean and Middle Eastern collections. Let me anticipate that before joining the Museum, I took entrance exams aimed at an effective professorship. Those exams included a list of themes covering the entire MAE collection, with its Ancient Mediterranean objects ranging from the Neolithic Age to the Byzantine period. I was really forced to study these materials in depth - I did not know them yet. I had just arrived from the French School of Athens, after 4 years of researches in France, where I earned my $\mathrm{PhD}$ (Caen and Paris) and 2 years at EFA. Since my areas of expertise were ceramics and iconography, I had to study quite different themes, objects and pieces for the first time. That experience explains my interest for the scientific treatment of a large part of the MAE collections.

An additional subject that permeates two publications I have worked on is my interest for Cyprus. When I was still at the French School of Athens, but already knew I was coming to the MAE - back then, MAA (Museum of Art and Archaeology) -, its director and professor Ulpiano Bezerra de Menezes ${ }^{1}$ requested me to study the Cypriot vases that had just arrived at the museum after being purchased by Professor Eurípedes ${ }^{2}$ from the Service of Antiquities in Nicosia. I created a small catalogue of this set, which comprised a piece from the Neolithic Age, an axe, an archaic lamp and 11 vases dated from the Ancient Bronze Age until the Roman period. In order to prepare this small catalogue, I had to initiate myself into the Cypriot bibliography. That catalogue was actually produced at the French School library. Professor Ulpiano sent me a list of those pieces, along with their pictures and a brief description. Based on them, I carried out a bibliographical research, produced a chronology and wrote the requested article.

Another involvement with the Near East and Middle East is related to a number of occasions when I traveled to those regions. I visited Turkey in 1973 at the time of the International Congress of Classical Archaeology in Ankara. I traveled through the region, and before participating in excavations in Syria, I traveled twice to Syria and Lebanon in contact with

\footnotetext{
${ }^{1}$ Emeritus Professor at FFLCH-USP. Prof. Ulpiano de Menezes was director of the MAE-USP, of the Prehistory Institute at USP, and also of Museu Paulista at USP.

${ }^{2}$ Eurípedes Simões de Paula, Professor of Ancient History at FFLCH-USP, where he was director. Prof. Eurípedes de Paula was also one of the founders and the first director of former MAA.
} 
some of my mother's relatives, who lived in Beirut. I also had an aunt in Kessab in Syria. And the third visit took place on occasion of Prof. Paul Courbin's excavations, which I will mention further on.

In addition to these reasons, there is another one that explains my attention to the Near East and the Levant, that is, the Levantine coast visà-vis Greece: namely my own origins. On the one hand, from my father's side, I am a descendant of Armenians from Cilicia, a region of Turkey that had a strong contact with Greece, especially Tarsus and Al-Mina; on the other hand, from my mother's side, I am a descendant of Assyrians a thing nobody knows. Because of my surname, people always think about the Armenians, but my mother was born in Urfa (currently in Turkey, an ancient Assyrian city of High Mesopotamia, named Edessa in the Hellenistic period). Urfa was almost totally inhabited by Assyrian descendants who were assimilated into the Armenian population in the region, and for this reason my mother's language was also Armenian. But my mother's name and surname - Behie Bessos - are not Armenian. Almost nobody knows this story, and the only person who really understood my connection with the Assyrians who lived in Urfa was Professor Helène Cassin, an Assyriologist. She became interested in knowing the history of the Bessos relatives of my family, who now live in Beirut, but also in Scotland and the United States, in addition to the aunt I had in Syria. It is worth mentioning, by the way, that there is an Assyrian community living here in São Paulo.

I am also interested in the Urartu civilization, which developed in present-day Armenia along Lake Van (currently in Turkey), where archaeologists have found great fortresses and citadels, including a very important one near the capital Yerevan, namely the city of Erebuni (an ancient, Urartian name of the capital that gave birth to Yerevan). What caused this interest was my participation in the Congress of Classical Archaeology in Turkey, previously mentioned, which took place in Ankara and Smyrna in 1973. At the Museum of Ankara, I learned about the bronze industry of the Urartu civilization, which comprises a large part of the materials exposed at the Museum of Ankara. Due to my origins, I started reading about the Urartu civilization and found articles that depict a heritage of Urartian metallurgy in Greece in the Geometric period, and also in Etruria. There are many hypotheses regarding contact among these peoples. For instance, in a book about Persia and the West, John Boardman states his belief that Urartians did not have direct contact with Greece or Etruria, ${ }^{3}$ but their heritage reached these regions via other

\footnotetext{
${ }^{3}$ John Boardman. Persia and the West: An archaeological investigation of the genesis of Achaemenid Persian art. London: Thames \& Hudson, 2000.
} 
cities in Asia Minor, with which the Greeks and Etruscans had contact.

I wrote an article about Urartu, which is another link that brings me closer to the East and to the things I find most interesting, particularly in the Ancient Mediterranean. This article is part of the catalogue of an exhibition on Armenian Sacred Art held at the São Paulo Pinacoteca in 2004 - "Armenia's History, Art and Archaeology. From Urartu to Etchmiadzin", p. 24-35. After the congress in Turkey, I visited Cyprus. And I knew the island of Cyprus quite well before its military events, i.e. before it was divided into Turkish and Greek sections. I was able to visit several archaeological sites and the Museum of Nicosia. With a second trip and new experiences in 1974, those places further drew my attention to the importance of Cyprus, placed as it is on an intersection between the Western and Eastern Mediterranean.

The final connection is due to the fact that during the period when Prof. Ulpiano directed the Museum, I was the only archaeologist working with the Ancient World there. Prof. Marianno ${ }^{4}$ had not yet arrived and was finishing his $\mathrm{PhD}$ in Paris. There were no internal regulations at the Museum; no division, sector or department - there was nothing of that sort. But there was a collection. I was the Head of the Mediterranean Sector at the MAE and I became interested in this sector. When Prof. Marianno arrived, he became Head of the Middle-Eastern Sector, including Assyriology and Egyptology. These collections already existed at the MAE. Soon after Prof. Marianno's passing in 1980, I returned from a 2-year research program in France, Syria and Greece, and Prof. Penteado $^{5}$ - who was the Museum's director then - appointed me by ordinance as Head of the Mediterranean and Middle-Eastern Sector. So I became also interested in the future of the Egyptian and Mesopotamian collections. With the aid of egyptologists from abroad, I trained an MSc and PhD student in Egyptology - Professor Antonio Brancaglion Junior, who currently has an outstanding scientific career at the UFRJ National Museum and at the French Institute in Cairo (IFAO). I attempted without success to train assyriologists, with the support of French experts. I also organized courses, presentations and round tables with national and international scholars of this area, particularly with Prof. Ciro Flamarion Cardoso (Egyptology, UFF Niteroi) and assyriologists Emanuel Bouzon (PUC RJ), Jean Bottéro (École Pratique des Hautes Études, Paris), and Helena Cassin (CNRS, Paris). More recently, as a remainder of a project proposed by Prof. Jean Bottéro, I coordinated a program with

\footnotetext{
${ }^{4}$ Professor Marianno Carneiro da Cunha, Assyriologist, earned his $\mathrm{PhD}$ at the École des Hautes Études en Sciences Sociales, Paris; d. 1980.

${ }_{5}^{5}$ Professor Antonio Rocha Penteado, from the Geography Department at FFLCH-USP and one of the directors of the MAE-USP.
} 
assyriologists Jean-Jacques Glassner (CNRS, Paris), Marcelo Rede (FFLCH-USP), and Kátia Pozzer (UFRGS).

(1)

HERÓDOTO (H.): You have worked on some occasions with the renowned French archaeologist Paul Courbin, and you even invited him to give a course at the MAE. In one of these collaborations, you participated in excavations under his direction in Ras el Bassit, Syria. Can you tell us more about your collaboration with Prof. Courbin and how was the work dynamic in those excavations?

H.S.: My first contact with Prof. Paul Courbin took place when I was a member of the French School of Athens between 1966 and early 1969. I participated in the excavations of Argos, a site that bears the mark of Prof. Courbin's presence, since he practically resurrected fieldwork techniques for the French School of Athens by practicing the methodology championed by Mortimer Wheeler. Courbin's rigor left a mark on the archaeology of Argos, which became a reference as a school of archaeology and field techniques. On that occasion, I participated in excavations with archaeologists trained by him, including the director of those excavations, Francis Croissant. Courbin was present in two seasons during the two years when I was excavating in Argos, at the Afrodision and the Agora. He was not excavating on the field; instead, he was studying the materials of his previous excavations at the museum. ${ }^{6} \mathrm{He}$ had been excavating in the 1950s, when he was a member of the French School, and later as Secretary-General of the School. He was the person who excavated the region of today's Argos Museum, a necropolis with extraordinary geometric materials, which he later published in two volumes, along with other findings. ${ }^{7} \mathrm{He}$ was the person behind the construction of the Museum of Argos, and now there is even a street in Argos with his name.

I met him and became very impressed with the rigor of his work and the way he analyzed the materials at the museum storage. And so we became close collaborators. Once in São Paulo in 1976, I invited him to give a course on field methodology and archaeological theory, covering the foundations of his work Qu'est ce que l'Archéologie? It was a really good course and many students attended it, in a time when professors spoke their native language and all students understood them without the need for translation. Our contact became closer and when he was already

\footnotetext{
${ }^{6}$ The Archaeological Museum of Argos.

${ }^{7}$ Paul Courbin. La Céramique Géometrique de l'Argolide, Vol. 1 et 2. Paris: Éditions E. de Boccard, 1966.
} 
excavating in Ras el Bassit, I asked him if I could participate in those excavations. I had an opportunity to be on leave from the Museum for 2 years with a scholarship sponsored by the French Government. It was a special scholarship aimed not at students, but at researchers.

So I went and first I spent one year in Paris, working at Prof. Courbin's lab at the School for Advanced Studies. ${ }^{8}$ The name of that lab was BEMA - Bureau d'Études des Méthodes Archéologiques. Courbin was already a professor at the School for Advanced Studies. He was very rigorous; he published only a few works and was an extremely systematic scholar. His nickname was "l'homme systhème". I spent one year at BEMA researching on ceramics and studying the fragments kept at the lab some of them were from Ras el Bassit. The academic year was 1978/1979. I also took part in excavations at Courbin's school site. That was a very important experience. The school site was in southern France, in a place named Bourg-St. Déol, near Grignan. I excavated a quadrant with Arno Kern; ${ }^{9}$ he was a PhD student in Paris under Courbin's supervision, and he also went to the school site. We worked together in the excavation of a quadrant under Courbin's supervision. Bourg-St. Déol was a GalloRoman site with stratigraphy, excavation techniques, profile preparation for drawings, topography and so on. I was accommodated at a country house owned by Courbin near Grignan, and then we returned to Paris. It was between March and April 1979, I remember it was really cold then. And in May, we headed to Syria.

That experience in Ras el Bassit was extremely important, not only on account of the field practice, but also of its findings. The Ras el Bassit site is identified as the ancient Greek outpost of Posideion, mentioned by Herodotus. ${ }^{10}$ In previous excavations, Courbin found extracts from the Late Bronze Age consistent with what Herodotus wrote about that city, which was allegedly founded by Achaean hero Amphilochus upon his return from the Trojan War. And after the Late Bronze Age, there are striking signs of Phoenician, Cypriot and Greek presence (here, one must point at Greek colonization starting in the $7^{\text {th }}$ century BC), along with Hellenistic and Roman levels. Ras el Bassit is a meeting point of Cypriots, Phoenicians and Greeks, and those excavations became a genuine school of archaeology.

During the excavations, each team member was entrusted with one quadrant and became the person responsible for the excavation, topography, drawings and studies of the materials obtained in it. We had

\footnotetext{
${ }^{8}$ École des Hautes Études en Sciences Sociales, Paris.

${ }^{9}$ Arno Kern, archaeologist, professor at UFRGS and CNPq Senior Researcher.

${ }^{10}$ Herodotus III, 91 .
} 
non-stop journeys starting at 5am (we woke up at 4am and then went to the site at $5 \mathrm{am})$, and we excavated until $2 \mathrm{pm}$ or $2: 30 \mathrm{pm}$. After lunch, we made a brief stop and went to the front of the Apotheke (the storage) built by Courbin himself. He built both the house where the archaeologists were accommodated and the Apotheke, and we then worked in front of it, in the open air. We sat at long tables and each one would study his or her materials. There we analyzed, washed, dried and tagged them, wrote their descriptions and ascribed their inventory and identification numbers. I worked with 90 bags of fragments found in my quadrant. They were small paper bags like the ones we commonly find at grocery stores, but they were not always full, since all depended on each finding's stratigraphy and location. That was a fantastic experience. Courbin was in charge of the most delicate excavations and controlled all quadrants, especially those with ceramic findings.

That experience allowed me to know the Ras el Bassit region, which is located approximately 40 kilometers from Latakia and 10 kilometers from Ugarit down the coast. I knew Ugarit well and also the archaeologists who were excavating there at that time. The excavation season lasted 60 days. I lost 7 kilos, and I was so thin. Courbin, as a good Chief of Expedition, took the entire team to excursions around the region on Sundays. So we got to know Latakia and Ugarit pretty well. On that occasion, I bought this Ugarit head (see figure 2), and we got to know Tell Sukas, a Danish excavation site with a stratigraphic succession more complete than ours in Ras el Bassit, which included other periods, and also identified the presence of Phoenicians, Canaanites, Cypriots and Greeks. We also toured Aleppo, which is now unfortunately destroyed, and visited the Museum of Aleppo where the Ebla (Tell Mardikh) materials were kept. It was a great joy for us to visit the Euphrates River.

The contact I had with Syria, Damascus and these excursions surprisingly led me to the Syrian consulate in São Paulo, where I was invited to organize a photo exhibition entitled "From Ebla to Damascus". I accepted their proposal and organized this exhibition in an amphitheater at USP. The consulate of Syria sponsored a cocktail reception and I gave a lecture on the archaeology of the Levantine coast. A lot of people showed up to hear it, including almost the entire local Syrian-Lebanese community; and shortly afterwards I was invited by the director of an African-Asian center to give the same lecture in the city of Londrina. I accepted this new invitation and gave this same lecture on the Levantine coast from Al Mina to Tell Sukas. So these were the outcomes of my participation in the excavations led by Courbin in Ras el Bassit. 
H.: In your career, you have been strongly interested in publishing part of the MAE-USP collection on Mediterranean Archaeology. Bearing in mind the thematic focus of Herodotus, we may highlight some projects you have pursued in order to publish MAE-USP objects, such as a funerary relief from Palmyra; a cult relief of the Mithraic tauroctony; and a replica of King Ahiram's sarcophagus. Can you briefly present these objects and make some comments on the importance of publishing them?

H.S.: I will speak first about the cult relief of the Mithraic tauroctony, which has been the object of one of my articles. This article was originally published by Revista de Antropologia in a poor edition (with 57 print mistakes). ${ }^{11}$ So I updated it and included it in the works I presented for my livre docência examinations. ${ }^{12}$ My interest in these objects was always linked to the circumstances of my travels. The Mithraic tauroctony relief was a piece in the collection of Guida Bezzi from Rio de Janeiro. Mrs. Bezzi inherited this collection from her grandfather Tommaso Gaudenzio Bezzi, the architect and engineer who built the Museu Paulista, i.e. Museu do Ipiranga. Prof. Ulpiano had already been in contact with her when I went once to Rio de Janeiro; I saw that relief and considered it to be very important. I asked her to let it go to the MAE under a commodate contract while we figured out if we could buy it. At that occasion, I also got to see some ceramics and several Greek and Roman coins; and rather naively, just like every young enthusiast, I went to a stationary shop and bought paper, cotton, cardboard, boxes and hand bags. Then I packed everything and brought these materials in a Rio-São Paulo flight, without insurance or anything else.

After I arrived at the Museum, Prof. Ulpiano requested funds to FAPESP13 and I wrote a scientific opinion, since without a scientific interest, FAPESP would not give us these funds - I mean the scientific interest of these pieces, the researches that could be made. And so FAPESP provided sufficient funds for buying these materials. Next, in one of my travels to participate as a member of the Scientific Committee for Lexicon, ${ }^{14}$ I met Maarten Vermaseren, who was a great expert in Mithraism and Mithraic iconography, and the author of the LIMC entry on Mithra. I talked to him about the relief we had here and he became interested in it. So I sent him photos, a description and its measures. He

\footnotetext{
${ }^{11}$ Haiganuch Sarian. Baixo-relevo cultual: Mitra Tauróctono. Revista de Antropologia, vol. 23, 1980, p. $141-59$.

${ }^{12}$ Haiganuch Sarian. Arqueologia da Imagem: expressões figuradas do mito e da religião na Antiguidade Clássica. Tese de Livre-Docência. Museu de Arqueologia e Etnologia da USP, 2005, p. 182-191.

${ }^{13}$ FAPESP is the Research Support Foundation of the State of São Paulo.

${ }^{14}$ Lexicon = LIMC = Lexicon Iconographicum Mythologiae Classicae.
} 
became really enthusiastic about it, since this relief was considered to be lost and was only known so far through drawings of $16^{\text {th }}$ century manuscripts - the central piece among these manuscripts was kept in Berlin. Due to the importance of this cult relief, he asked permission to publish it. I talked to Prof. Ulpiano, who authorized its publication. I sent Vermaseren some other photos made by Iolanda Huzak, who used to make photos for the Museum, and he wrote the book Mithriaca IV.15

Vermaseren dedicated this book entirely to this Mithraic relief. After publishing it, I sensed it would be interesting to publish something in Portuguese about the Mithra relief, not only for people in Brazil to learn about the existence of this really important MAE piece, but also because Vermaseren did not undertake a complete iconographical study. That was not his aim, since he was more focused on the history of this relief starting with the older collection and the manuscripts that mentioned it. So I had the idea of writing an article in the form of an expanded review of this book. And when I prepared the materials of the volume I presented for my livre docência exams, I decided to resume work on this article and add drawings, photos and a more detailed iconographical study of it, along with the most recent bibliographical references on it.

The importance of this relief is not only historical, but is also related to the scene it depicts: Mithra sacrificing a bull. This is originally an IndoIranian myth that moved through Mesopotamia, the Near East and Asia Minor, to reach the entire Roman Empire - and also Greece. However, the Mithraic religion did not succeed at all in Greece as in the Roman world. The relief dates back to the $2^{\text {nd }}$ century $B C$, and it is interesting to see that the Greeks did not assimilate the Mithraic religion until much later, i.e. until the days of Neoplatonism, though much less than in the Roman Empire. There is a text by Momigliano which says, in this regard, that if Mithra did not speak Greek, at least he did speak Latin. ${ }^{16}$ But the important element here is that the Mithraic myth did not have an iconographic expression, and it only acquired such iconographic expression due to the influence of Hellenistic art, possibly in Pergamon.

Thus the iconographic scheme of Mithra sacrificing the bull is the same as that of Heracles and Theseus fighting the bull of Crete and the bull of Marathon. The up and down torches of Cautes and Cautopates, the two servants attending on Mithra, are a typical feature of Greek iconography; in sum, the entire art and iconography of Mithraism that expanded throughout the Roman Empire is originally Greek. It is a transposed

15 Mithriaca IV: Le monument d'Ottaviano Zeno et le culte de Mithra sur le Célius. Leiden: E.J.Brill,1978.

${ }^{16}$ Arnaldo Momigliano. Os limites da Helenização. Rio de Janeiro: Jorge Zahar Editor, 1991. 
Greek scheme; having emerged in the Indo-European world, it was largely successful in the Roman world, through the Mithraic mysteries and initiations (even Roman emperors were initiated in these mysteries). All this demonstrates the extraordinary importance of the Mithraic tauroctony relief.

The funerary relief from Palmyra is even more interesting. It came from the Tapajós Hipp collection, from Rio de Janeiro. ${ }^{17}$ Tapajós Hipp inherited the Hahn collection from a Berlin collector whose brother-in-law was a curator and archaeologist at the Berlin Museum. This relief was bought from the Tapajós Hipp collection and when Prof. Ulpiano was the director of the Museum, he thought that - as Hipp himself had said - the inscription was written in Aramaic.

However, when I was participating in the works at BEMA, before starting his excavations - which were practically the beginning of several archaeological seasons of the Ministry of Foreign Affairs (Ras el Bassit was an archaeological mission abroad funded by the Ministry of Foreign Affairs, as well as some other missions in many spots of the world, even in Peru) -, Courbin offered a cocktail reception at BEMA for the archaeologists involved in the excavations in Syria. And so the Ugarit archaeologists, and many other archaeologists, also attended this reception, including those who were studying Palmyra. At this reception I met Javier Teixidor, who was a great expert on Semitic inscriptions. I told him about this inscription we had in a Palmyra relief in the MAE collection, and I did not know whether it was written in Aramaic or in another language. He said that if it were a funerary bust, then its inscription would be referring to the dead person represented in the bust. He asked me to send him a photo, which I did upon my return to São Paulo. Teixidor identified this bust in the corpus of Semitic inscriptions of 1948,18 with a simple and rather inaccurate drawing of its inscriptions, followed by the note: "lapidis fata ignoramos" (we ignore the fate of this tombstone).

He then wrote me to say this piece was listed in the 1948 corpus and ended up in Brazil. He asked for our permission to publish it and I spoke to Prof. Ulpiano, who promptly gave it. Hence its publication in the bulletin of Semitic epigraphy in the Siria journal in 1974, with a photo of the relief I had sent him and including the correct transcription of the inscription on that small plaque and the inscription on its side. ${ }^{19}$ The inscription is actually a funerary formula about a character, Malkû. It

\footnotetext{
${ }^{17}$ Which belonged to collector Franz Hermann Edgar Tapajós Hipp.

${ }^{18}$ CIS - Corpus des inscriptions sémitiques II, 4293.

${ }^{19}$ Javier Teixidor. Bulletin d'épigraphie sémitique, 1974. Vol. 51, n. 3, p. 334.
} 
reads: "Oh Malkû, son of Ogâ, alas!" (hélas! in the French translation of the journal). He dated it back to the second half of the $3^{\text {rd }}$ century AD, and the inscription on that small plaque is only the name of a dead: Malkû. My correspondence with Teixidor prompted me to write an article about that funerary relief. After the Ras el Bassit excavations, I went to Palmyra and saw several funerary reliefs at the local museum, visited the necropolis and the hypogea, made several photos and collected a large number of documents, which I am always updating whenever I see a new publication on Palmyra sculptures (there is a recent, co-authored publication by Bounni, who was the director of antiquities at the time when I excavated in Ras el Bassit, about the funerary busts and the art of funerary sculptures in Palmyra). ${ }^{20}$ This inscription was not written in Aramaic, but in Palmyrene dialect, which was a variation of Aramaic.

Finally, King Ahirom's sarcophagus (an expert recently informed me that the correct spelling is Ahirom, not Ahiram, from Byblos). I went several times to Lebanon and Beirut because of some relatives from my mother's side; and in the three occasions when I was there before the civil war, I visited the original sarcophagus at the National Museum of Beirut. I quickly became interested in the origin of the writing, that is, of the inscription on it. This is a very interesting story, because this sarcophagus - which is made of limestone - has some painting and relief remains. The sarcophagus dates from the $13^{\text {th }}$ century $\mathrm{BC}$, but it was reused in the $10^{\text {th }}$ century $\mathrm{BC}$ and its inscription was added on this second occasion. It is the oldest known inscription in Phoenician alphabet.

My interest started at the time of Professor Eurípedes, when this replica came to the Museum. Prof. Eurípedes and his wife Regina attended an event in Beirut, where they met Emir Maurice Chehab ('Emir' is a nobility title equivalent to 'Sir'), who was a legendary figure in Syrian archaeology. I also met him in connection with the LIMC. There you have it: always the LIMC (which gathered 40 countries)! Well, Prof. Eurípedes was in contact with Emir Maurice Chehab and visited the National Museum of Beirut guided by him. Prof. Eurípedes saw the original sarcophagus in a special room of the Museum, and a replica of it in its storage section. So he requested its donation, and the Lebanese Government sent it to the MAE. Prof. Eurípedes published then an article about this sarcophagus in the Revista de História, which I do have. ${ }^{21}$ And it happened that Prof. Maria Cristina de Oliveira Bruno, a museologist and

\footnotetext{
20 Anna Sadurska; Adnan Bounni. Les sculptures funéraires de Palmire. Supplementi alla Rivista di Archaeologia, 13. Rome: G. Bretschneider, 1994.

${ }^{21}$ Eurípedes Simões de Paula. O sarcófago do rei Ahiram de Biblos. Revista de História, n. 72, 1967, p. $321-7$.
} 
the current MAE director, thought about creating an exhibition set for the room where the replica was, but it would then be necessary to restore it, among other things.

I was asked to collaborate to the exhibition project, and I did some researches during my visits to Greece. But long before that, I had requested a mold of the inscription on the sarcophagus. I took several photos in Athens, including in 2008 with Ana Luiza (an excellent photographer who participated in my excavations in Delos in 2008), in addition to photos from old books showing the excavation site where the sarcophagus was found and the team of archaeologists from Byblos. Finally, I obtained photos of the original sarcophagus from Beirut. I proposed five photographic panels: 1 . Phoenicia and the Phoenicians (maps and photos); 2. Byblos and its necropolis (blueprint and photos); 3. The sarcophagus, iconography (photos and drawings); 4. The sarcophagus and its inscriptions; 5 . The Phoenician alphabet and the genealogical tree of Western alphabets.

The inscriptions on the sarcophagus are quite interesting. They read: "[This] sarcophagus [was] made by Ithoba'al, son of Ahirom, king of Gebal [the Phoenician name of the city], for Ahirom his father, as his abode in eternity". And the inscriptions on the lid affirm: "And if a king among kings and a governor among governors should come up against Gebal and uncover this sarcophagus, may the scepter of his power be broken, may the throne of his royalty be overturned, and may peace reign in Gebal. As for him, his memory shall be effaced in the afterworld". This inscription is not only relevant for the history of writing in the West, as a great invention, but its contents are extremely important for the field of funerary practices. However, despite all efforts, our exhibition did not take place. The sarcophagus' replica recently became again an object of discussions at the MAE, since it needs to be restored before resuming the previous project of the exhibition set.

H.: You have studied the emergence of the Greek alphabet in the context of exchanges among Greeks, Cypriots and Phoenicians. Can you please say more about this setting and how it enabled the appearance of Greek alphabet and writing?

H.S.: Once again, we refer to my involvement with the MAE pieces. The replica of king Ahirom's sarcophagus was donated by the Lebanese Government to the University of São Paulo during Miguel Reale's term ${ }^{22}$

\footnotetext{
${ }^{22}$ Miguel Reale, Full Professor at the Law School, USP, was twice USP rector.
} 
and exposed at the Museum with a really short caption, and I tried to improve the information about the original piece. It coincided with one of my trips to Beirut. I went to the museum ${ }^{23}$ and visited the original sarcophagus - a very beautiful limestone piece, well located in the museum, with its painting and relief remains. I obtained good photos of the original sarcophagus and requested a restorer to provide a plaster copy of the entire inscription. As I just mentioned, this is considered the most complete and oldest inscription with the Phoenician alphabet; for practical purposes, it is the starting point of the Phoenician alphabet.

During my travels, I read beyond the focus of my main research at the libraries I visited. I always dedicated some time to examine museum objects other than ceramics, which was the main object of my studies. And in addition to this curiosity about the Phoenician alphabet, when I participated in the excavations in Ras el Bassit, I learned about the cuneiform tablet ${ }^{24}$ (kept at the Archaeological Museum of Damascus) discovered in Ugarit, which contains the earliest known alphabet (from the $14^{\text {th }}$ century BC). It is a school-like alphabet with 30 letters, including 22 letters that gave birth to the Phoenician alphabet.

Before participating in the excavations in Ras el Bassit, I undertook an indepth study of Cyprus ceramics - the ceramics that can be seen in the small MAE catalogue. Driven by my curiosity, I also came across two articles: one of them, written by Courbin on the fragments of a Cycladic vase found in Ras el Bassit; and the other, written by Roger Saidah, who was a very important Lebanese archaeologist, probably published in Berytus - a Lebanese journal on archaeology - about the necropolis of Tambourit, near Tyre. There, Saidah had found a geometric Greek pyxis associated to an amphora in one and the same tomb. The amphora was produced locally but in a Cypriot style, and it curiously had a Phoenician inscription indicating the toponym "Aqmata", which seems to be the origin of the amphora's content. Aqmata is a location. ${ }^{25}$

\footnotetext{
${ }^{23}$ National Museum of Beirut.

${ }^{24}$ Prof. Sarian pointed at a replica of a tablet with the Phoenician alphabet in cuneiform script (see figure 2).

${ }^{25}$ Roger Saidah. Une tombe de l'Age du Fer à Tambourit. Berytus: Archaeological Studies 25, 1977, p. 135-146; Paul Courbin. Fragments d'amphores Protogéométriques Grecques a Bassit (Syrie). Hesperia 61, 1, 1993, p. 95-113.
} 


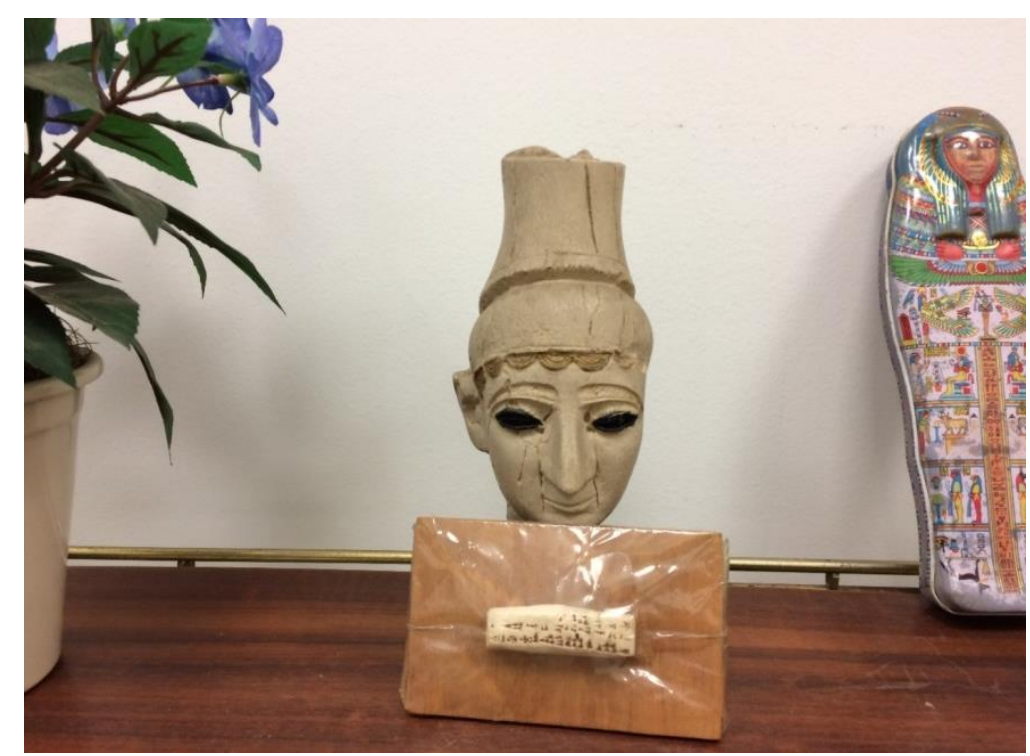

Figure 2: Replicas of a head and of the cuneiform script tablet, both from Ugarit, on a shelf in Professor Sarian's room.

I found this was a curious finding and started to make approximations. When we organized the MAE exhibition on the alphabetic writing - I do not quite remember the name of that exhibition, but it was very successful ${ }^{26}$ - for almost an entire year, I made researches on inscriptions starting with cuneiform writing and then moving on to the Phoenician, Greek, Etruscan and Latin alphabets. I started to outline an article, which not only provided me with some close approximations regarding the Levantine coast (and this seemed to be the aim of my endeavor), but also led me into a study of Cyprus. I read an article in which Jean Irigoin called attention to the fact that the Greeks of the period known as the "Greek Renaissance" were neither the inventors of the vowels, nor the ones who added them to the Phoenician alphabet; instead, vowels are a product of the Mycenaean period, i.e. of Mycenaean Linear B script. The Linear B script is a derivation of Cretan Linear A script and it disappeared in continental Greece, but still survived in Cyprus until a very recent period in the $3^{\text {rd }}$ century $B C$. It was used not only to express Greek enunciations and the Greek language, but also to express the local, native Eteocypriot language.

I rapidly made an approximation and found Jeffery's reference, ${ }^{27}$ stating that the Greek alphabet probably emerged in a cultural area in which

\footnotetext{
${ }^{26}$ This was the 1998 exhibition "A Escrita do Mundo Antigo" ["The Writing of the Ancient World"].

${ }^{27}$ Lilian H. Jeffery. The local scripts of archaic Greece. A study of the origin of Greek alphabet and its development from the eighth to the fifth centuries BC. Oxford: Clarendon Press, 1961.
} 
Greeks, Cypriots and Phoenicians were circulating. So here was the answer to the conundrum. I studied the relations among Greece, Cyprus and the Levantine coast, from Cilicia, Tarsus and Al Mina, then going through Ras el Bassit, where Greek materials were found abundantly (including the Cycladic fragments published by Courbin); and later, down the coast to Ugarit with its tablet, then further down to Tell Sukas, where Greek and Cypriot materials were also found. This can be noticed along the entire Phoenician coast, down to the region of present-day Lebanon and in Byblos; near Byblos, in King Ahirom's sarcophagus, with its first great inscription; and in the vicinity of Tyre, at the Tambourit site, where three cultural remains from Greece, Cyprus and Phoenicia appear together in one single tomb.

That was my research itinerary. I also learned, as it evolved, about a predecessor of Phoenician writing in the Mount Sinai region: the ProtoSinaitic script. It appeared in a region of Egyptians, where many hieroglyphic inscriptions were found, but it was also an area of several Phoenician inscriptions, i.e. inscriptions with signs that were similar to the signs later recorded in the Phoenician alphabet. This was a region of traders. It is quite likely that Egyptian traders went to the Sinai region in search of the turquoise gem that appears in many objects produced during the period of the pharaohs, and it is likely that Levantine merchants also visited this same region and left their inscriptions around $1600 \mathrm{BC}$. These inscriptions seem to be at the root both of the Ugaritic alphabet and of the Phoenician alphabet recorded in King Ahirom's sarcophagus.

H.: Professor Sarian, you are a great expert in iconographic studies. One of the many themes you have studied regards iconographic borrowings, for instance in iconographies of the Erinyes in Greece and Etruria. Another notable borrowing provided the structure for the iconography of Perseus beheading the Gorgon. Can you please tell us about these studies and explain how they reveal some relations between the Greek world and the "East"?

H.S.: The issue of iconographic borrowings has always been a concern in the numerous studies I made, and I believe there is still a lot to be researched and published in regard to it. My article on the Erinyes in Greece and Etruria was published in the proceedings of a colloquium organized by the Lexicon program. The colloquium was held in Paris in 
1983 and published in the $14^{\text {th }} \mathrm{BCH}$ supplement. ${ }^{28}$ This volume includes many chapters: Greece, Rome, Etruria, and peripheral regions. However, I had the idea of exploring the Erinyes theme from Greece to Etruria, and I attempted, without success, to continue this research line with some graduate students. It takes a great deal of erudition to handle this theme, and I thought about exploring Greek iconographical themes in the Italiote milieu, then moving to Etruria and to the Roman sarcophagi.

Regarding iconographic borrowings, the case of Perseus beheading the Gorgon emerged from a classroom experience. As I taught a lesson on the Attic lekythos of the MAE collection, which depicts an image of Perseus fleeing with the Gorgon's head, I started to explore this iconographic scheme and reached at some interesting conclusions, which I subsequently presented to the students in another lesson and finally converted into a research. I gathered a substantial bibliography on this topic and some photos. And I still keep all these materials in a folder, but I have not yet had the time to roll up my sleeves, undertake a careful analysis of this bibliography and publish this study. In fact, the conclusion I reached - which already appears in some bibliographical titles - is that the Gorgon's head or Gorgoneion emerges both in literary texts and in the iconography from before the episode in which Perseus beheads the Gorgon. Gorgoneion images date back to the Minoan period in Greece, with masks that clearly resemble the Gorgon, and similarly to some masks from Syria - a Mesopotamian region - that resemble the mask of Humbaba, a mythological figure from Babylon. So I drew a parallel between these representations.

Later on, I started to examine Mesopotamian masks that appear in cylinder seals and to study the iconography of these cylinder seals. I noticed a scheme of a male figure facing forward with his body turned to the left, while decapitating an animal figure. This scheme evolved toward an enhanced form that appeared in Syria around the $8^{\text {th }}$ century BC, in which a male figure holds the harpe, i.e. the sickle-sword that appears in Perseus' iconography, as he decapitates a monster with a mask-like face. This can be interpreted as a scene from the Gilgamesh epic, in which Gilgamesh is decapitating Humbaba. But I would have to gather several testimonials in order to affirm this, and so far I have not had the time to do it. The most interesting thing here is that, on the one hand, we see the Assyrian civilization from northern Syria; and, on the other, we have the

\footnotetext{
${ }^{28}$ Haiganuch Sarian. Réflexions sur l'iconographie des Érinyes dans le milieu grec, italiote et étrusque. In: Actes du Colloque International du CNRS no.619/Paris, 1983, Paris. Iconographie Classique et Identités Régionales. Atenas/Paris : École Française d'Athènes, 1986. p. 25-35. Haiganuch Sarian. Erinys. In: Fondation Internationale pour le LIMC. (Org.). Lexicon Iconographicum Mythologiae Classicae. 1 ed. Zurique: Artemis Verlag, 1986, v. 3, p. 825-843.
} 
Greek world.

Going through the bibliography, I found a cylinder seal from Cyprus dating back to the $7^{\text {th }}$ century $\mathrm{BC}$, currently kept in Berlin, which iconographic scheme is precisely the same, but its interpretation is dubious: some authors mention Gilgamesh beheading Humbaba, while others cite it as one of the oldest known schemes of Perseus beheading the Gorgon. I personally believe it is Perseus beheading the Gorgon, because of its location - Cyprus -, where the elements for an approximation with the Greek world were much stronger than with the Mesopotamian world. So I outlined the structure of an article, showing that the scene of Perseus beheading the Gorgon is cited by Hesiod (Theogony, 276-280), but not by Homer. In Homer, we find the Gorgoneion only. Now, Hesiod's Theogony originated from Mesopotamian cosmogony. Here we can see several coincidences: Hesiod and the Theogony; the Hesiodic episode in which Perseus beheads the Gorgon; and the Cypriot cylinder seal from the same period, which, in my interpretation, depicts Perseus beheading the Gorgon.

Based on these evidences, I arrived at the provisional conclusion that the episode in which Perseus beheads the Gorgon originates from a figuration transmitted from the East to the Cypriot and Greek world. And it is no coincidence that such transmission took place during the so-called Orientalizing period. So this topic does contain an itinerary of ideas. I once gave a lecture in one of the congresses held by SBEC 29 in Araraquara - I do not quite remember the year - with the title "The Orientalizing adventure in Greece", in which I explored Ekrem Akurgal's publication, La naissance de l'art grec, with his studies on the approximation between Asia Minor and Greek art in that period. I explored Boardman and a MAE piece - a koûros head. And I finished the lecture speaking precisely about this issue of borrowing an iconographic scheme, with the scenes of Gilgamesh beheading Humbaba, and Perseus beheading the Gorgon.

The koûros head at the MAE is a Cypriot sculpture that led me to a research on archaic sculptures in Cyprus. It really is heir to Assyrian sculpting, when we consider its straightforwardness and hairstyle: it is so similar to the Assyrian sculptures of its time. I once was talking to Rolf Stucky, a Swiss colleague who was a member of the French School of Athens, while he was excavating in the coast of Lebanon - that was a private excavation in an ephemeral Swiss mission in Byblos. I showed him a photo of the MAE sculpture and he said: "oh, this is interesting. A quite similar koûros head was found at the temple of Eshmun and is now

\footnotetext{
${ }^{29}$ The Brazilian Society of Classical Studies.
} 
kept at the National Museum of Beirut". He somehow got a picture of it to show me. It even seemed those two sculptures were produced by the same sculptor. And it is quite likely that the MAE head actually came from the temple of Eshmun in Byblos.

It has been thoroughly restored and underwent $\mathrm{X}$-ray exams. By the way, many years ago, Bia and Mabel ${ }^{30}$ took this head to a hospital here at the university for an X-ray, and it was possible to see its restoration and several nails. But the essential elements are there with their original style, so a comparison with the Beirut head is possible. It is interesting that this koûros head was bought from a Rio de Janeiro collection during Ulpiano's term of office, the Tapajós Hipp collection, from which many objects came to the Egyptian sector at the MAE. Tapajós Hipp inherited this collection from the former Hahn collection from Berlin (collector Hahn had a brother-in-law who was a curator at the Archaeological Museum of Berlin). I believe that, following the advice of his brother-in-law, Hahn possibly bought this head from a region not far from Lebanon, considering the other head found at the temple of Eshmun. Here we see, once again, my involvement with Cyprus and the Levantine coast.

H.: In recent decades, you have directed excavations in an archaeological site on the island of Delos, the Heraion (Sanctuary of Hera). This is one of the most ancient shrines on Delos, and some of its neighboring sanctuaries were dedicated to Egyptian deities such as Isis and Serapis. Can you please tell us something about the Heraion excavations, its findings and the circumstances of the approximation between those Greek and Egyptian cults in the Hellenistic period?

H.S.: I effectively started researching the Delos Heraion in 2000, though I had been entrusted with this responsibility long before, when former EFA director Olivier Picard asked me to study the Heraion ceramics and to expand Dugas' publication. ${ }^{31}$ I had not been to Greece for 6 years and upon my return there in 1996, I had a serious conversation with Roland Étienne, who was the EFA director at that time. I told him I had reflected on this project and I thought that studying the ceramics without connecting them to the sanctuary would not be interesting, and that my main concern had always been the study of archaeological units, so I wanted to approach the Hera sanctuary in its totality, not only studying

\footnotetext{
${ }^{30}$ Maria Beatriz Borba Florenzano and Maria Isabel d'Agostino Flemming. Both are leading scholars at LABECA (Studies Lab on Ancient Cities) and LARP (Provincial Roman Archaeology Lab), respectively, at MAE-USP.

${ }^{31}$ Charles Dugas. Les Vases de l'Héraion. Exploration Archéologique de Délos 10. Paris: E. De Boccard, 1928.
} 
the temples but also doing prospections and examining the materials published in the 1920s and 1930s. He agreed with me. I had this same conversation with Phillip Bruneau, and he also agreed it was an excellent idea. My argument was based on the probings carried out during Pierre Roussel's first excavations in 1911, then by Paul Bernard in 1958, and by Jean Ducat in 1964. Those had been limited probing occasions in which excavations only lasted for a week, but they produced good results in terms of clues for continuing to excavate.

In a nutshell, the original excavations from the period of the grande fouille of the French School of Athens found two temples in the sanctuary of Hera - an earlier temple embedded in the cella of a more recent one - and an utterly important and voluminous votive deposit with the ceramic materials published by Charles Dugas in 1928, along with the terracotta statuettes and protomes published by Laumonier, I believe, in 1956.32 And in 1928, the same year of Charles Dugas' publication, Plassart published a volume on sanctuaries and cults of the Mount Cynthus region, 33 including a long chapter not only about the architecture and the altar of the Heraion, but also about some of its findings.

Due to a lack of infrastructure, it was not possible for me to follow a program of excavations and probing, and to excavate in a systematic way. For instance, in 2000, our work was focused only on ceramic materials and we studied mostly fragments of the first excavation that had not yet been published, along with the findings of Jean Ducat's and Paul Bernard's probing. In 2002, I started excavating with the specific objective of obtaining clarifications on the so-called eskhára, i.e. a sort of bóthros that was built next to the altar. We recovered the fragments of this small construct and the interior of the cella, the interior of the pronáos and the connection between the more recent temple and the retaining wall at the terrace of the temples.

In sectors $\mathrm{A}, \mathrm{B}, \mathrm{C}$ and $\mathrm{D}$ of these excavations, $\mathrm{I}$ found quite a large number of Hellenistic materials, which made me suspect that the sanctuary had also been visited in the Hellenistic period. This was only known through inscriptions and the inventories of Delos. Archaeologically, there was virtually nothing but the altar (which really dates back to 305 in the Hellenistic period). There was a second season of excavation at the sanctuary's entrance in 2006 (by the way, you, Gilberto, participated in the 2006 and 2008 seasons; and in three other seasons, we

\footnotetext{
${ }^{32}$ Alfred Laumonier. Les figurines de terre cuite, 2 vol. Exploration Archéologique de Délos 23. Paris: E. De Boccard, Paris, 1956.

${ }_{33}$ André Plassart. Les sanctuaires et les cultes du mont Cynthe. Exploration Archéologique de Délos 11. Paris: E. De Boccard, 1928.
} 
only worked on the material at the Delos Museum storage). In the 2006 season at the sanctuary's entrance, we confirmed its attendance during the Hellenistic period. And finally, in the 2008 season, which continued Jean Ducat's probing and linked it to Paul Bernard's probing, we were able to attest the attendance to the sanctuary above all in the Geometric period, which is a really important finding.

In the 2008 season, the materials from the Geometric period stood out among our findings, and some Hellenistic materials appeared in the higher levels. However, with these three excavation seasons and the observations at the museum ${ }^{34}$ about the materials from the previous excavations and two subsequent probings, and above all after observing the materials of the votive deposit, we arrived at a chronology that does not quite follow the currently established one. Plassart's publication and the Guide de Délos ${ }^{35}$ reiterate that the beginning of cult activities at the Heraion was in the first half of the $7^{\text {th }}$ century until approximately the year $500 \mathrm{BC}$, i.e. the time of Leagros. There is also a short account of the results of Jean Ducat's probing, which does not insist in the chronology about the first temple.

My conclusion, which still needs further verification, is that the Heraion and its sanctuary as a whole had their cult activities started as a small temple in the second half of the $8^{\text {th }}$ century BC, thus in the Geometric period, and this initial temple was later embedded in the cella of the second and more recent one. This is confirmed not only by the 2008 excavations, but also by some fragments from the Geometric period, including recent Geometric vases and pomegranate replicas found in the votive deposit, which were not sufficiently explored for the first Heraion chronology. And later on, the final period in the construction of the second temple is more recent than one had imagined, according to the analysis of the more recent ceramic materials of the votive deposit, which dates from $480 \mathrm{BC}$ and not to $500 \mathrm{BC}$.

This is already a good result for grasping the attendance to the sanctuary. But it is important to stress that there was a considerable gap between the first quarter of the $5^{\text {th }}$ century BC and the Hellenistic epoch, which corresponds to the period of Delian independence between 314 and 167 $\mathrm{BC}$. This is precisely the period when the Egyptian sanctuaries and also the Syrian sanctuary appeared in this terrace, which started being referred to as 'the terrace of the foreign gods'. In the history of Delos, this does not explain the absence of attendance to the Heraion in the Classical

\footnotetext{
${ }^{34}$ The Archaeological Museum of Delos.

${ }^{35}$ Plassart, Op. cit.; Philippe Bruneau \& Jean Ducat. Guide de Délos. 4èmme éd. Paris; Athènes: E. De Boccard, 2005.
} 
period - this is actually a great issue, a great doubt, which, to my understanding, can be related to a new study of the chronology of the Zeus and Athena sanctuary on Mount Cynthus. If I had more time, I would examine the materials found in this one temple, as it seems that the success of the Zeus and Athena sanctuary somehow obscured attendance to the temple of Hera in the Classical period. So there may have been a gap of attendance to the Heraion in the Classical period and a substitution, due to the success of the Zeus and Athena sanctuary on Mount Cynthus.

However, the foreign population of Delos increased in the Hellenistic period, for commercial reasons. Delos was then a very important port between the coast of the Levantine Near East and Italy. Therefore, many merchants either went to or lived in Delos, and they also built numerous sanctuaries to their gods on this island. Near the Heraion, one finds the Sarapieion $B$ temple. Three shrines were dedicated to Serapis in the vicinity of the Inopos River and of the Heraion terrace: the Sarapieion A and $\mathrm{C}$ temples and the Isis temple near the sanctuary of Hera. There is no direct link between these two deities. But this region's renaissance, with the emergence of foreign worship practices, consequently brought back the cult of Hera. Thus, an altar was erected during this period, and attendance increased in the Hellenistic period. The inscriptions describe the careful tending of the statue of Hera, ceiling rearrangements and the consecration of pinakes at the temple. So I believe there was a religious rebirth in this region, and the sanctuary of Hera was influenced by the increase of these Egyptian cults. A sign of this process is the fact that the Heraion's large retaining wall was rearranged in the Hellenistic period in such way that it was extended and also served as a limit for the sanctuary of Serapis.

I do not see a relation of cults. Instead, I identify an intense blossoming of this region on this terrace and also down near the Inopos River. As a consequence, a rebirth of the cult of Hera took place. Not to mention the element of chance in the excavations, because the large Heraion terrace has not been fully excavated, and I do not know whether somebody will someday find materials from the Classical period. We are always dealing with the current state of the art of an issue.

H.: The archaeological researches under your direction in the Hera sanctuary in Delos (excavations and lab analyses) found a large quantity of Orientalizing ceramics produced at 'Eastern Greece' workshops. Can you please comment on the current status of these findings and on how 
they interfere in your interpretation of the chronology of the cult of Hera in Delos?

H.S.: Chronology is not a very important issue for dating these two temples, since the Eastern Greek vases at the Heraion come from the votive deposit. The big findings of the excavations under my direction are not related to materials that are representative of Eastern Greece. Instead, they are connected with ceramic materials from the sanctuary's favissa from the $7^{\text {th }}$ and $6^{\text {th }}$ centuries $\mathrm{BC}$, and they are important from the chronological standpoint only because they reveal a consistent attendance at the temple in that period. There are excellent materials in Rhodes: for instance, the wild goat style; in Chios, for instance, as represented by some magnificent chalices; in northern Ionia; and in Naucratis in Egypt. These are some of the centers that produced the vases we found at the Heraion.

From a chronological standpoint, we are always facing the $7^{\text {th }}$ and $6^{\text {th }}$ centuries BC. However, the biggest problem is not so much chronology, but: how did those vases get to the Heraion? What kind of attendance do we find there? Were these worshippers from Ionia, or did the vases come from intermediary centers and were taken by Cycladic worshippers? This is a very delicate issue, and it does not apply exclusively to the Delos Heraion, as we bear in mind that substantial similar materials were discovered by John Boardman in his excavations in Chios and Tocra (Cyrenaica in Libya). Some of these findings are quite voluminous, for instance, the findings in Rhodes. To begin with, there are nearly 30 vases of the type Dugas called vases-couronnes (which are, in fact, askói). So, in the specific case of the Hera sanctuary, were those vases exported from Eastern Greece to the Cyclades and bought by inhabitants of Delos or of nearby places, who then took them to the sanctuary and offered them to Hera? Or was her shrine visited by Ionians on account of the strong importance of Apollo's sanctuary? This is not only an issue that regards the Heraion, but, indeed, a Delian issue. 